\title{
Analysis of morphological and functional maturation of neoislets generated in vitro from pancreatic ductal cells and their suitability for islet banking and transplantation
}

\author{
M R Katdare, R R Bhonde and P B Parab \\ National Centre for Cell Science, NCCS Complex, Pune University Campus, Ganeshkhind, Pune 411007, India \\ (Requests for offprints should be addressed to P B Parab; Email: pbparab@nccs.res.in)
}

\begin{abstract}
The pancreatic ductal stem cells are known to differentiate into islets of Langerhans; however, their yield is limited and the islet population is not defined. Therefore, the aims of the present study were to improvise a methodology for obtaining large numbers of islets in vitro and to characterize their morphological and functional status for islet cell banking and transplantation.

Pancreatic ductal epithelial cell cultures were set in serum-free medium. Monolayers of epithelial cells in culture gave rise to islet-like clusters within 3-4 weeks. The identity of neoislets was confirmed by dithizone staining and analysis of the gene expression for endocrine markers by reverse transcriptase-polymerase chain reaction (RT-PCR). The islet population obtained was analysed by image analysis and insulin secretion in response to secretagogues.
\end{abstract}

The cellular extracts from neoislets were immunoreactive to anti-insulin antibody and expressed insulin, glucagon, GLUT-2, PDX-1 and Reg-1 genes. The islets generated within 3-4 weeks exhibited a mixed population of large- and small-sized islets with clear cut dichotomy in the pattern of their insulin secretion in response to L-arginine and glucose. These neoislets maintained their structural and functional integrity on cryopreservation and transplantation indicating their suitability for islet cell banking. Thus, the present study describes an improved method for obtaining a constant supply of large numbers of islets from pancreatic ductal stem cell cultures. The newly generated islets undergo functional maturation indicating their suitability for transplantation.

Journal of Endocrinology (2004) 182, 105-112

\section{Introduction}

Successful islet transplantation for the treatment of diabetes requires an adequate supply of insulin-producing endocrine tissue. It has been reported previously that partial or subtotal pancreatectomy in streptozotocin (STZ)-induced diabetic mice leads to pancreatic regeneration and subsequent reversal of experimental diabetes (Brockenbrough et al. 1988, Hardikar et al. 1999), indicating the potential of the pancreas for islet cell neogenesis and regeneration. It has been well established that the adult pancreatic duct harbours stem cells for islet neogenesis in mice (Ramiya et al. 2000) as well as in humans (Bhattacharya et al. 1995, Gmyr et al. 2001) which can be expanded in vitro for islet generation. Recently, attention has been focused on the possible use of controlled differentiation of stem cells to obtain specialized cells useful in treating many diseases (Vogel 1999). Adult pancreatic duct cells have the potential to lose their specific ductal phenotype and revert back to pluripotent stem cells that can differentiate into islet cells with the appropriate external stimuli such as various growth factors (Cornelius et al. 1997). Although these studies are of potential interest, they have inherent limitations including unavailability of sufficient number of islets for transplantation. Cryopreservation of neoislets may also open the possibility of pooling of the neoislets to match the requirements for transplantation. Therefore, the present studies were undertaken to improvise and simplify the existing methodology for getting large numbers of islets in vitro and to characterize their morphological and functional status and their suitability for transplantation.

\section{Materials and Methods}

\section{Chemicals and media}

All chemicals and immunochemicals used in the studies were purchased from Sigma Chemical Co., St Louis, MO, USA. The Protein Estimation kit (BCA) was obtained from Pierce Chemical Co., Rockford, IL, USA and the Insulin ELISA kit was from BioSource, Nivelles, Belgium. Media and antibiotics were obtained from Gibco-BRL, 
Gaithersberg, MD, USA and plastic ware was from Nunc, USA (Naperville, IL, USA).

\section{Initiation of ductal epithelial cultures}

Pancreata were dissected from 6 to 8 weeks old balb/c mice and were digested with $0 \cdot 1 \%$ collagenase for $20 \mathrm{~min}$ at $37^{\circ} \mathrm{C}$. The cellular pellet was washed with plain RPMI 1640 medium and resuspended in complete medium (RPMI 1640/10\% FCS). Adult pancreatic ductal fragments were individually isolated from the collagenase digest and plated into 6-well tissue culture plates precoated with rat tail collagen $(200 \mu \mathrm{g} / \mathrm{ml})$ as described previously (Ramiya et al. 2000) and were incubated at $37^{\circ} \mathrm{C}$ in a $\mathrm{CO}_{2}$ incubator for $48 \mathrm{~h}$. After $48 \mathrm{~h}$ the floating population which includes acinar cells and islets, if any, was totally removed and the medium was replenished by serum-free medium (Bonner-Weir et al. 2000). The medium contained DMEM/Ham's F12 (DMEM with $0 \cdot 45 \%$ glucose, $110 \mathrm{mg} / 1$ sodium pyruvate, $0 \cdot 1 \mathrm{mM} / 12$-mercaptoethanol) with the following supplements: $1 \mathrm{~g} / 1$ ITS supplement (5 mg/l of each of insulin, transferrin and selenite), $2 \mathrm{~g} / 1$ BSA, $10 \mathrm{mM}$ nicotinamide and $10 \mathrm{ng} / \mathrm{ml}$ keratinocyte growth factor (KGF). Medium was supplemented with $200 \mathrm{U} / \mathrm{ml}$ penicillin and $100 \mathrm{U} / \mathrm{ml}$ gentamycin. Cultures were replenished with fresh medium every third day until substantial patches of epithelial cells were formed. These cultures were characterized by cytokeratin 19 (CK-19) staining, a ductal epithelial cell marker. Within 3-4 weeks, a sizeable number of islet-like clusters started to appear in the culture. These islets were collected at different time intervals and stained with dithizone (DTZ) to assess the presence of insulin-producing cells (Bonner-Weir et al. 2000). DTZ stains insulin containing cells brick red. The in vitro generated islets exhibited variation in their size. Hence these cells were subjected to image analysis and separated according to their size using the Kontron image analysis system (Kontron Elektronik $\mathrm{GmbH}$, Munchen, Germany) connected to a Zeiss microscope. The total number of islets generated exceeded 13000 islets per culture in 16 weeks. Similar results were obtained from three cultures prepared at different times.

All procedures carried out in these studies were reviewed and approved by the National Centre for Cell Science's Institutional Animal Care and Use Committee and were in compliance with guidelines set out by the Committee for the Purpose of Supervision of Experiments on Animals (CPSEA) of the Government of India.

\section{Immunocytochemistry}

The epithelioid nature of the cells obtained in pancreatic ductal cultures was confirmed by using epithelial cell markers. In brief, 3-week old epithelial cultures grown on sterile glass coverslips were fixed with $2 \%$ paraformaldehyde (PFA) and then permeabilized with $0.5 \%$ Triton
X-100. Cells were blocked with 1\% BSA and incubated with primary antimouse CK-19 antibody. For detection of primary antibody, a fluorescent-labelled secondary antibody, rabbit antimouse IgG-FITC, was utilized. Cells were examined with a Zeiss LSM 510 confocal microscope equipped with argon and helium lasers (Zeiss, Jena, Germany).

\section{$R N A$ extraction and analysis}

The neoislets were collected periodically from 4 weeks onwards from the culture and stored at $-70{ }^{\circ} \mathrm{C}$. Total RNA was extracted from regenerated islets following the manufacturer's protocols using TRIzol Reagent. Reverse transcription reaction was carried out using total RNA $(500 \mathrm{ng})$ at $50{ }^{\circ} \mathrm{C}$ for $30 \mathrm{~min}$. The PCR conditions were 35 cycles of $94^{\circ} \mathrm{C}(1 \mathrm{~min})$, annealing temperature $(1 \mathrm{~min})$, $72{ }^{\circ} \mathrm{C}(1 \mathrm{~min})$. The final extension was at $72{ }^{\circ} \mathrm{C}$ for $10 \mathrm{~min}$. The respective sequences of the PCR primers, the annealing temperature and the expected product size from the mRNA of each gene were as follows: $\beta$-actin, sense $5^{\prime}$-ATCCGTAAAGACCTCTATGC- $3^{\prime}$, antisense 5' AACGCAGCTCAGTAACAGTC-3' (55 $\left.{ }^{\circ} \mathrm{C}, 286 \mathrm{bp}\right)$; insulin-1, sense $5^{\prime}$ CCTGTTGGTGCACTTCCTACC$3^{\prime}$, antisense $5^{\prime}$-CAGTAGTTCTCCAGCTGGTA-3' $\left(55^{\circ} \mathrm{C}, 314 \mathrm{bp}\right)$; glucagon, sense $5^{\prime}$-GGTGCAAGGCA GCTGGCAG-3', antisense 5'-CCTGGTGGCAAGA TTGTCCAG-3' $\left(55^{\circ} \mathrm{C}, 453 \mathrm{bp}\right) ;$ GLUT-2, sense $5^{\prime}$ AGATCGGCTCTGACGTGAGG-3', antisense $5^{\prime}$-GA GGAACCGTCCAAGAATGAG-3' $\left(55^{\circ} \mathrm{C}, 418 \mathrm{bp}\right)$; Reg-1, sense 5'-CATCTGCCAGGATCAGTTGC-3', antisense 5 -AGGTACCATAGGACAGTGAAGC-3' $\left(55^{\circ} \mathrm{C}, 549 \mathrm{bp}\right) ;$ PDX-1, sense $5^{\prime}$-CAGTGAGGAG CAGTACTAC-3', antisense 5'-GATGTGTCTCTCG GTAAGTTC-3' $\left(50{ }^{\circ} \mathrm{C}, 569 \mathrm{bp}\right)$.

\section{Immunoblotting}

Adult mouse islets and islets obtained from pancreatic ductal cell cultures were sonicated in PBS, and kept at $4{ }^{\circ} \mathrm{C}$ overnight for extraction. The protein concentration was determined using the BCA kit. Samples were analysed by SDS-PAGE, transferred on nitrocellulose membrane and incubated with rabbit anti-mouse insulin antibody. After thorough washing, membranes were incubated with anti-rabbit Ig conjugated with alkaline phosphatase diluted 1:1000 with PBS/T overnight at room temperature, and after repeated washings nitrocellulose membranes were developed with BCIP/NBT substrate.

\section{Insulin and DNA content}

Glucose and L-arginine challenge experiments Adult and fetal balb/c mouse islets were prepared by the method described previously (Shewade et al. 1999). Newly generated islets were collected and sorted by size into two 
groups. Three hundred islets from each group (in triplicate) were put in tissue culture plates containing $100 \mu \mathrm{l}$ Krebs-Ringer bicarbonate buffer $(\mathrm{pH} 7 \cdot 4)$ supplemented with $10 \mathrm{mmol} / 1$ HEPES and $1 \mathrm{mg} / \mathrm{ml}$ bovine serum albumin $(\mathrm{KRBH})$. The plates were then incubated at $37^{\circ} \mathrm{C}$ in $\mathrm{CO}_{2}$ for $2 \mathrm{~h}$. After incubation, the supernatant from each well was collected and stored at $-70{ }^{\circ} \mathrm{C}$ before estimation of preincubation insulin levels.

Freshly isolated islets from fetal and adult pancreata and those regenerated in vitro (small and large size islets) were challenged with L-arginine and/or glucose to study their insulin secretory response. The islets from different groups were incubated with either $1.5 \mathrm{mM}$ L-arginine or $5 \mathrm{mM}$ glucose in KRBH (Shewade et al. 1999, Ramiya et al. 2000) at $37^{\circ} \mathrm{C}$ for $2 \mathrm{~h}$. The supernatant was collected and the media were replaced by $10 \mathrm{mM}$ L-arginine and $20 \mathrm{mM}$ glucose in $\mathrm{KRBH}$ and again incubated at $37^{\circ} \mathrm{C}$ for $2 \mathrm{~h}$. At the end of this incubation, the insulin levels in the supernatants were estimated using the Insulin-ELISA kit. DNA content was determined using DNAzol genomic DNA isolation reagents (ICN Biochemicals, Ohio, USA) according to the manufacturer's instructions, from 300 islets each of adult islets, fetal islets and harvested neoislets of both sizes.

\section{Cryopreservation and revival}

The newly generated and adult mouse islets (1000 islets each) were cryopreserved by Cryomed at a cooling rate of $1{ }^{\circ} \mathrm{C}$ per min and were stored in liquid nitrogen. These vials were revived after 6 months, and their viability was checked by trypan blue dye exclusion test. Both the cultures containing cryopreserved neoislets and islets isolated from adult pancreas were washed with plain medium and incubated in RPMI 1640/10\% FCS medium for $4 \mathrm{~h}$ at $37{ }^{\circ} \mathrm{C}$ for stabilization. After incubation, islets were collected and washed twice with plain $\mathrm{KRBH}$ and these islets were then challenged with glucose as described earlier. Insulin levels were estimated from preserved media with the Insulin-ELISA kit.

\section{Transplantation of islets into diabetic mice}

$\mathrm{Balb} / \mathrm{c}$ mice (8 to 10 weeks old) were injected with a single dose of $200 \mathrm{mg} \mathrm{STZ} / \mathrm{kg}$ body weight. Fifteen diabetic mice (blood sugar $>250 \mathrm{mg} / \mathrm{dl}$ ) were divided into three groups ( $n=5 /$ group). Animals in group 1 were transplanted intraperitoneally with 500 newly generated islets and those of group 2 were transplanted with islets collected from adult normal pancreas. Animals in group 3 were treated as positive controls. Blood glucose levels were estimated after $24 \mathrm{~h}$ and then after every alternate day up to 20 days by a glucometer (Accurex). Animals were not monitored further for glucose levels as our goal was only to assess functional status of the regenerated islets.

\section{Statistical analysis}

The results were analysed by Student's $t$-test using the Sigma Stat Software program (SPSS Inc., Chicago, IL, USA). The data are presented as the mean \pm S.E. of triplicate readings in one representative of, at least, three individual experiments.

\section{Results}

\section{Initiation of ductal epithelial cells and islet generation}

After $48 \mathrm{~h}$, fragments of pancreatic duct were found attached to the rat tail collagen-coated extracellular matrix; at this stage it was ensured that there was no contamination of pre-existing islets in the cultures (Fig. 1A). Small colonies of epithelial-like cells appeared throughout the culture plate. The number of colonies obtained and the time of their appearance depended largely on the type of extracellular matrix and the presence of appropriate growth factors such as KGF, nicotinamide, etc. in the culture medium. Keratinocyte growth factor used in the medium is a known stimulant for the growth of epithelial cells. Subsequently, these small colonies grew into confluent monolayers within a span of two weeks. These epithelial cell monolayers stained positive with CK-19 antibody, a marker for ductal epithelial cells (Fig. 1B). Similarly, these epithelial cell cultures were stained with DTZ and photographed periodically after the 2nd and 4th weeks. At the 2nd week, the epithelial cell sheets did not show any characteristic staining of insulin-producing cells (Fig. 1C), whereas by the 4th week insulin-producing cells/islets having the characteristic brick red colour were seen (Fig. 1D). Thus harvested neoislets stained positive with DTZ and appeared brick red in colour indicating their identity as insulin-producing islets. The presence of insulin in newly generated islets was also confirmed by immunoblotting when the characteristic band of insulin at $6 \mathrm{kDa}$ molecular mass was seen (Fig. 2). Approximately 13 000-16 000 neoislets were obtained in each successive experiment (three consecutive experiments).

\section{Morphological and functional assessment of newly generated and mature islets}

The data from the Kontron image analysis system revealed the presence of two populations of islets generated in vitro. The average area measurement of small-sized islets was $1324 \cdot 3 \pm 49 \cdot 3$ (S.E.) $\mu \mathrm{m}^{2}$ whereas that of large-sized islets was $7957 \cdot 5 \pm 316 \mu \mathrm{m}^{2}$ (Fig. 3). These two populations of islets when subjected to L-arginine or glucose exhibited a differential response with respect to insulin secretion (Table 1). Levels of insulin secretion were normalized to islet cell DNA as $\mu \mathrm{IU} / \mu \mathrm{g}$ DNA. The DNA content of 300 islets each of adult islets, fetal islets, small $\left(<1324 \mu \mathrm{m}^{2}\right)$ and large $\left(>1324 \mu \mathrm{m}^{2}\right)$ regenerated islets 

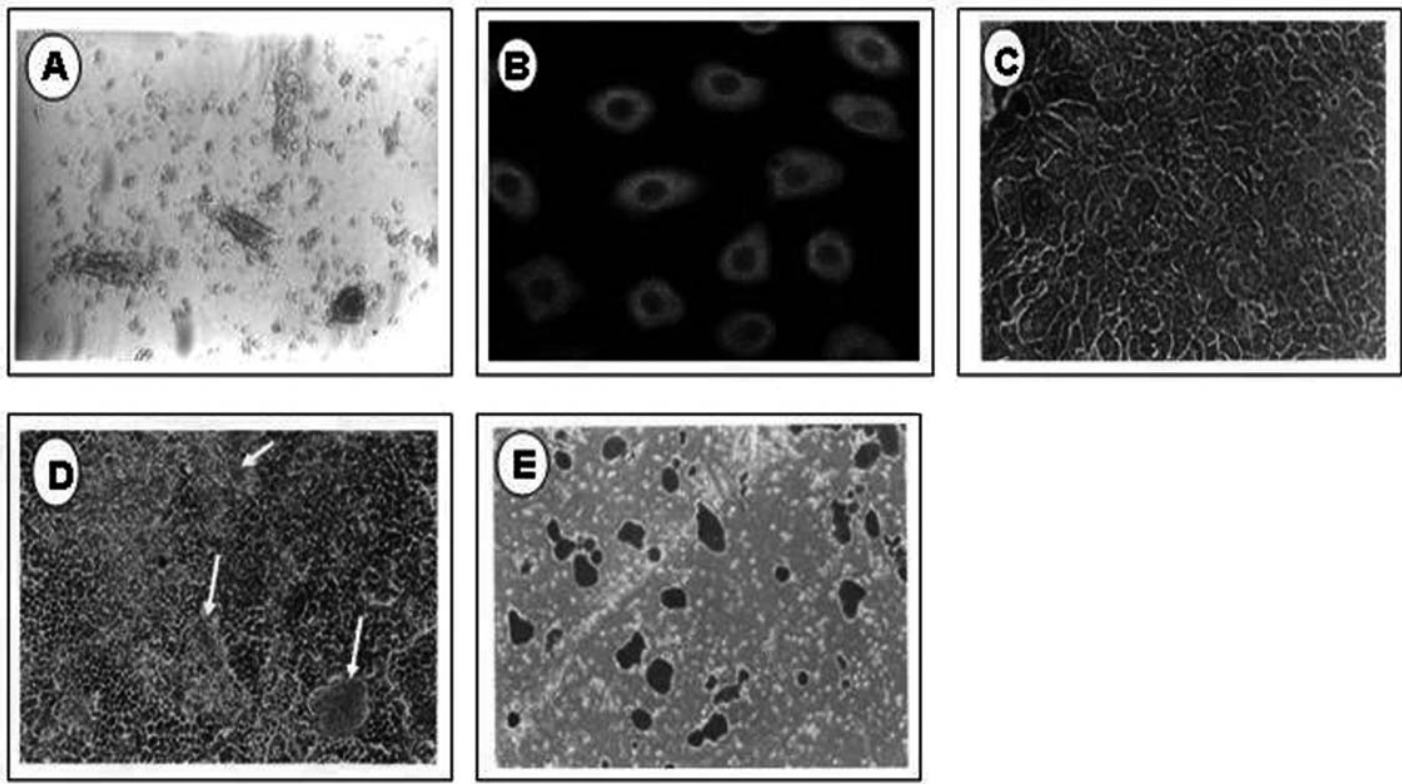

Figure 1 (A) Mouse pancreatic ductal fragments in cultures (magnification $\times 100$ ). (B) Ductal epithelial phenotype characterized by anti CK-19 fluorescent antibody (magnification $\times 1000$ ). (C) Ductal epithelial cell sheet (after the 2nd week) stained with DTZ. None of the cells showed characteristic DTZ staining (magnification $\times 100$ ). (D) Ductal epithelial cell sheet (after the 4th week) stained with DTZ. Only insulin producing cells/islets showing characteristic DTZ brick red staining are present (arrows) (magnification $\times 200$ ). (E) Harvested neoislets stained brick red with DTZ (magnification $\times 100)$.

were $195 \mu \mathrm{g} / \mathrm{ml}, 150 \mu \mathrm{g} / \mathrm{ml}, 95 \mu \mathrm{g} / \mathrm{ml}$ and $145 \mu \mathrm{g} / \mathrm{ml}$ respectively. Newly generated islets (approx. $<1324 \mu \mathrm{m}^{2}$ ) gave a vigorous $(12 \cdot 88 \pm 0 \cdot 25$ (S.E.) $\mu \mathrm{IU} / \mu \mathrm{g}$ DNA, $P<0 \cdot 001)$ response in terms of insulin secretion when challenged with $10 \mathrm{mM}$ L-arginine compared with neoislets (approx. $>1324 \mu \mathrm{m}^{2}$ ), fetal islets, and islets isolated from adult pancreas. There was a striking similarity between neoislets $\left(>1324 \mu \mathrm{m}^{2}\right)$ and islets isolated from

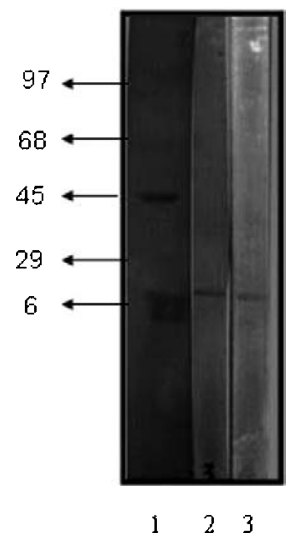

Figure 2 Immunoblot showing presence of insulin in islets generated from pancreatic ductal epithelial cells. Lane 1, molecular weight marker; lane 2, adult mouse islet extract showing the $6 \mathrm{kDa}$ insulin-specific band; lane 3, neoislet extract showing the $6 \mathrm{kDa}$ insulin-specific band. adult pancreas in insulin secretory response to a glucose challenge i.e $9 \cdot 18 \pm 0 \cdot 19 \mu \mathrm{IU} / \mu \mathrm{g}$ DNA and $5 \cdot 27 \pm$ $0 \cdot 18 \mu \mathrm{IU} / \mu \mathrm{g}$ DNA respectively when challenged with $20 \mathrm{mM}$ glucose (Table 2). Insulin secretion was reduced by a half i.e $6.92 \pm 0 \cdot 14 \mu \mathrm{IU} / \mu \mathrm{g}$ DNA when small islets were challenged with glucose as compared with arginine. We also observed that small islets and fetal islets responded vigorously only to L-arginine as compared with glucose stimulation in terms of insulin secretion.

\section{Endocrine gene expressions in newly generated islets}

Characteristic features of newly generated islets were further analysed by gene expression of endocrine pancreatic markers using RT-PCR analysis. mRNA expressions of insulin, glucagon, GLUT-2, PDX-1 and Reg-1 genes were observed by RT-PCR. The PDX-1 gene represents the endoderm whereas insulin, glucagon, and GLUT 2 genes represent highly specific pancreatic islet genes (Fig. 4). GLUT-2 is involved in glucose-stimulated insulin seceretion and Reg- 1 is responsible for the regeneration of islets from ductal epithelium.

\section{Cryopreservation and revival studies}

To determine the possibility of islet cell banking, cryopreservation and revival studies were carried out with regenerated neoislets $\left(>1324 \mu \mathrm{m}^{2}\right)$ in comparison with 


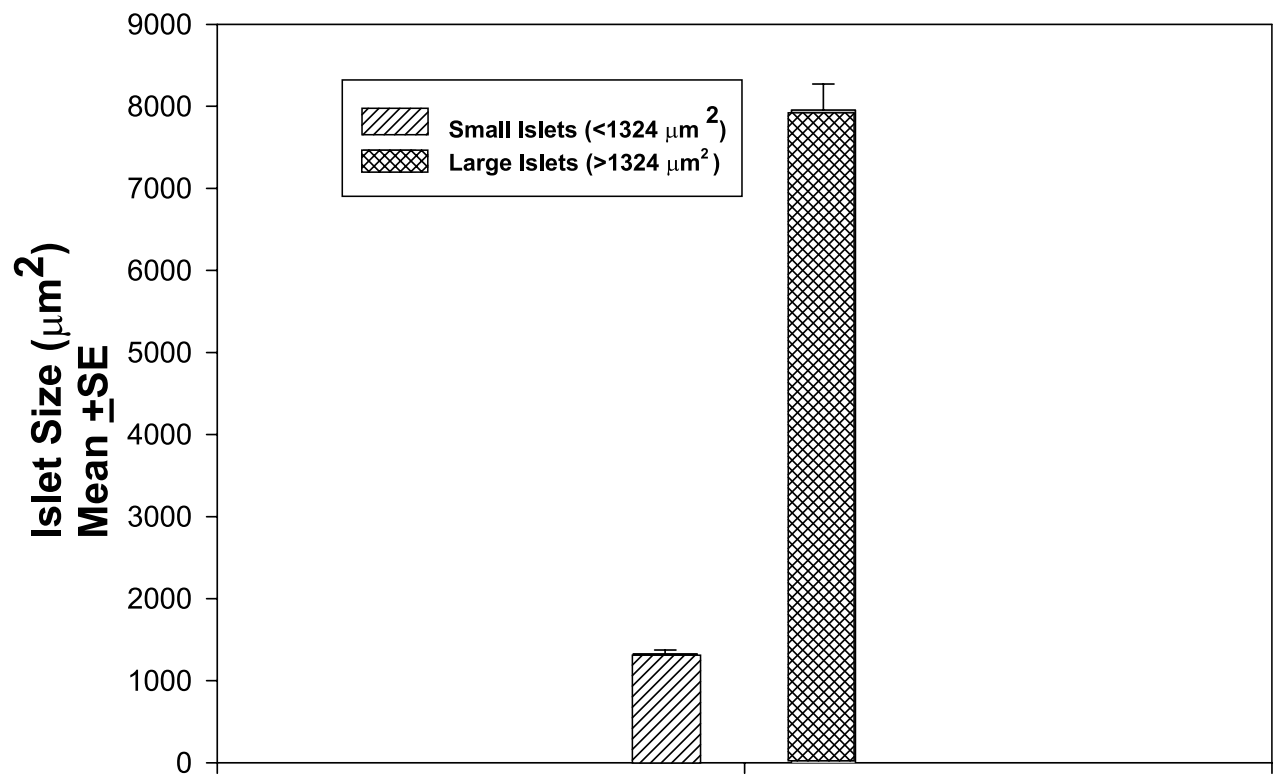

\section{Islets}

Figure 3 Size distribution of newly generated islets.

islets isolated from adult pancreas. The insulin secretory response of newly generated and freshly isolated adult islets before and after cryopreservation revealed a similarity of response to a glucose challenge. In response to a $20 \mathrm{mM}$ glucose challenge, neoislets were found to secrete $1291 \pm 7 \cdot 1 \mu \mathrm{IU}$ insulin/ml before cryopreservation and

Table 1 Insulin secretion (expressed as $\mu \mathrm{IU} / \mu \mathrm{g}$ DNA) by the newly generated islets (small-sized $<1324 \mu \mathrm{m}^{2}$ and large-sized $>1324 \mu \mathrm{m}^{2}$ ) and islets isolated from normal fetal and adult mouse pancreas, in response to L-arginine. Three hundred islets were challenged with various concentrations of L-arginine. Results are expressed as means \pm S.E. of triplicate readings and are the results of one of the three individual experiments

\begin{tabular}{|c|c|c|c|c|}
\hline & \multicolumn{4}{|c|}{ Insulin secretion $(\mu \mathrm{IU} / \mu \mathrm{g} \mathrm{DNA})$} \\
\hline & $\begin{array}{l}\text { Regenerated islets } \\
\left(<1324 \mu \mathrm{m}^{2}\right)\end{array}$ & $\begin{array}{l}\text { Regenerated islets } \\
\left(>1324 \mu \mathrm{m}^{2}\right)\end{array}$ & $\begin{array}{l}\text { Fetal } \\
\text { islets }\end{array}$ & $\begin{array}{l}\text { Adult } \\
\text { islets }\end{array}$ \\
\hline \multicolumn{5}{|l|}{ L-Arginine (mM) } \\
\hline 0 & $0 \cdot 88 \pm 0.09$ & $0.40 \pm 0.06$ & $0 \cdot 23 \pm 0 \cdot 05$ & $0 \cdot 21 \pm 0 \cdot 02$ \\
\hline $1 \cdot 5$ & $9 \cdot 39 \pm 0 \cdot 21$ & $3 \cdot 93 \pm 0 \cdot 47$ & $1 \cdot 87 \pm 0 \cdot 07$ & $2 \cdot 66 \pm 0 \cdot 01$ \\
\hline $10 \cdot 0$ & $12 \cdot 88 \pm 0 \cdot 25$ & $4 \cdot 26 \pm 0 \cdot 45$ & $3 \cdot 86 \pm 0 \cdot 35$ & $2 \cdot 90 \pm 0 \cdot 02$ \\
\hline
\end{tabular}

Table 2 Insulin secretion (expressed as $\mu \mathrm{IU} / \mu \mathrm{g}$ DNA) by the newly generated islets (small-sized $<1324 \mu \mathrm{m}^{2}$ and large-sized $>1324 \mu \mathrm{m}^{2}$ ) and islets isolated from normal fetal and adult mouse pancreas, in response to D-glucose. Three hundred islets were challenged with various concentrations of glucose. Results are expressed as means \pm S.E. of triplicate readings and are the results of one of the three individual experiments

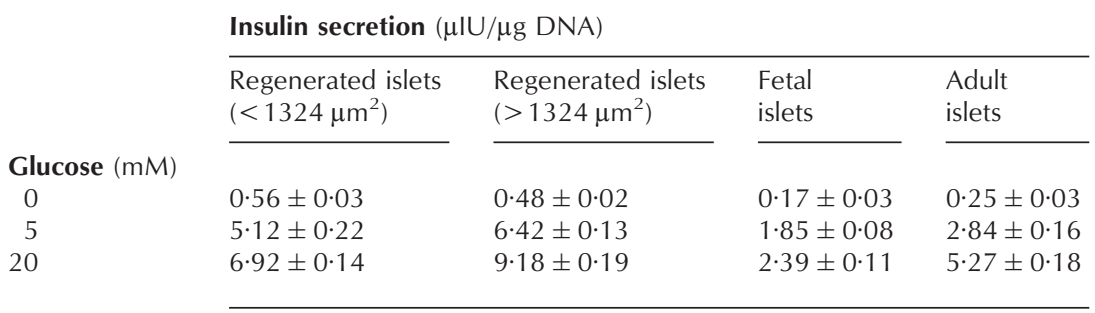




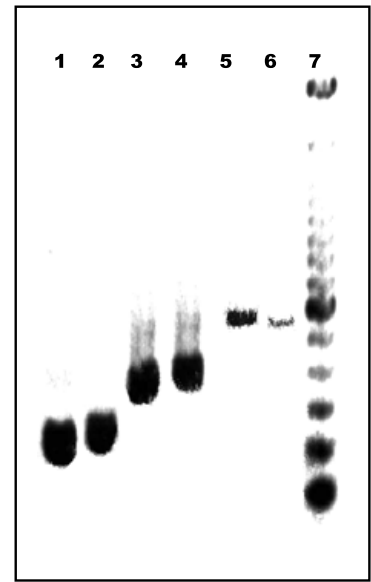

Figure 4 RT-PCR showing mRNA expression of lane 1, actin; lane 2, insulin; lane 3, GLUT-2; lane 4, glucagon; lane 5, PDX-1; lane 6, Reg-1 genes in newly generated islets; and lane 7, 100 bp marker.

$764 \cdot 4 \pm 26 \cdot 4 \mu \mathrm{IU}$ insulin/ml after revival whereas islets isolated from adult pancreas were found to secrete $1442 \pm 15 \cdot 3 \mu \mathrm{IU}$ insulin $/ \mathrm{ml}$ and $851 \cdot 4 \pm 14.9 \mu \mathrm{IU}$ insulin/ml respectively (Table 3 ). Although both the islet populations showed a generalized reduction in insulin secretion after revival following a glucose challenge, these islets were found to be fully functional. The reduction in insulin secretion could be attributed either to a loss of islet cell viability i.e. $14 \%$ in the case of adult islets and $21 \%$ in the case of revived regenerated islets or because of culture conditions as reported previously by Nielsen et al. (2002).

\section{Transplantation studies}

The neoislets were transplanted intraperitoneally in diabetic mice to assess their functional integrity in terms of insulin secretion in vivo. Five hundred islets each from adult mouse pancreas and regenerated neoislets were transplanted intraperitoneally into STZ-induced diabetic $\mathrm{balb} / \mathrm{c}$ mice. After $24 \mathrm{~h}$ of transplantation a decrease in blood glucose was recorded in group 1 animals $262.6 \mathrm{mg} / \mathrm{dl}$ on day 0 to $187.8 \mathrm{mg} / \mathrm{dl}$ on the $3 \mathrm{rd}$ day and
$184.6 \mathrm{mg} / \mathrm{dl}$ on the 5 th day $(P<0.001)$. The reduction in circulating blood glucose levels was significant on the $3 \mathrm{rd}$ and 5th days in both the groups treated either with neoislets or with islets isolated from adult pancreas (Fig. 5). Although there was a slow rise in blood glucose levels observed after 7 days in treated animals, these levels still remained lower in comparison with their diabetic counterparts, i.e. group 1, 227.9 mg/dl, group 2, $251.9 \mathrm{mg} / \mathrm{dl}$ and group $3,336.4 \mathrm{mg} / \mathrm{dl}$ on the 20 th day.

\section{Discussion}

It has been well established that the islet precursor cells are epithelial in nature with a ductal phenotype (Slade 1995). Pancreatic ductal stem cells can differentiate by neogenesis under the influence of various growth factors, and give rise to islets (Gu \& Sarvetnik 1993, Bhattacharya et al. 1995, Bonner-Weir et al. 2000). Techniques reported previously by Bonner-Weir et al. (2000) and Ramiya et al. (2000) for regeneration of islets from pancreatic ductal cells are very exciting for the future field of islet transplantation. However, fine tuning and optimization of each step of the procedure has been advocated including the ductal cell source, its expansion, growth factors and differentiation in vitro prior to envisaging a clinical application (Gmyr et al. 2001).

In the present studies we have established a methodology for the generation of neoislets from normal balb/c mouse ductal stem cells which was found to be reproducible in three consecutive experiments. We have modified and improved the protocol for obtaining ductal precursor cell monolayers. The epithelioid nature of these precursor monolayer cells was confirmed by positive immunofluorescence for the ductal cell marker CK-19 as also reported previously (Gmyr et al. 2001). It was further confirmed that the islets generated are truly 'de novo', as these cultures were periodically stained with DTZ. Secondweek epithelial cultures did not show the presence of any insulin-producing cells/or islets; these only appeared from the 4th week onwards as evidenced by their characteristic brick red colour. The functional characteristics of the

Table 3 Insulin release $(\mu \mathrm{lU} / \mathrm{ml})$ from normal and newly generated islets before and after cryopreservation, in response to glucose stimulation. Three hundred islets were challenged with various concentrations of glucose before and after revival. The results are means \pm S.E. of triplicate readings and are the results of one of the three individual experiments

\begin{tabular}{|c|c|c|c|c|}
\hline & \multicolumn{4}{|l|}{ Insulin $(\mu \mathrm{IU} / \mathrm{ml})$} \\
\hline & \multicolumn{2}{|l|}{ Normal islets } & \multicolumn{2}{|c|}{ Newly generated islets } \\
\hline & Before & After & Before & After \\
\hline \multicolumn{5}{|c|}{ Glucose (mM) } \\
\hline 0 & $86 \cdot 1 \pm 7 \cdot 7$ & $29 \cdot 4 \pm 2 \cdot 46$ & $79 \cdot 3 \pm 3 \cdot 8$ & $17 \cdot 3 \pm 1 \cdot 1$ \\
\hline 5 & $655 \cdot 0 \pm 11 \cdot 2$ & $526 \cdot 4 \pm 7 \cdot 6$ & $971 \cdot 8 \pm 5 \cdot 1$ & $513 \cdot 0 \pm 6 \cdot 1$ \\
\hline 20 & $1442 \cdot 0 \pm 15 \cdot 3$ & $851 \cdot 4 \pm 14 \cdot 9$ & $1291 \cdot 0 \pm 7 \cdot 1$ & $764 \cdot 4 \pm 26 \cdot 4$ \\
\hline
\end{tabular}




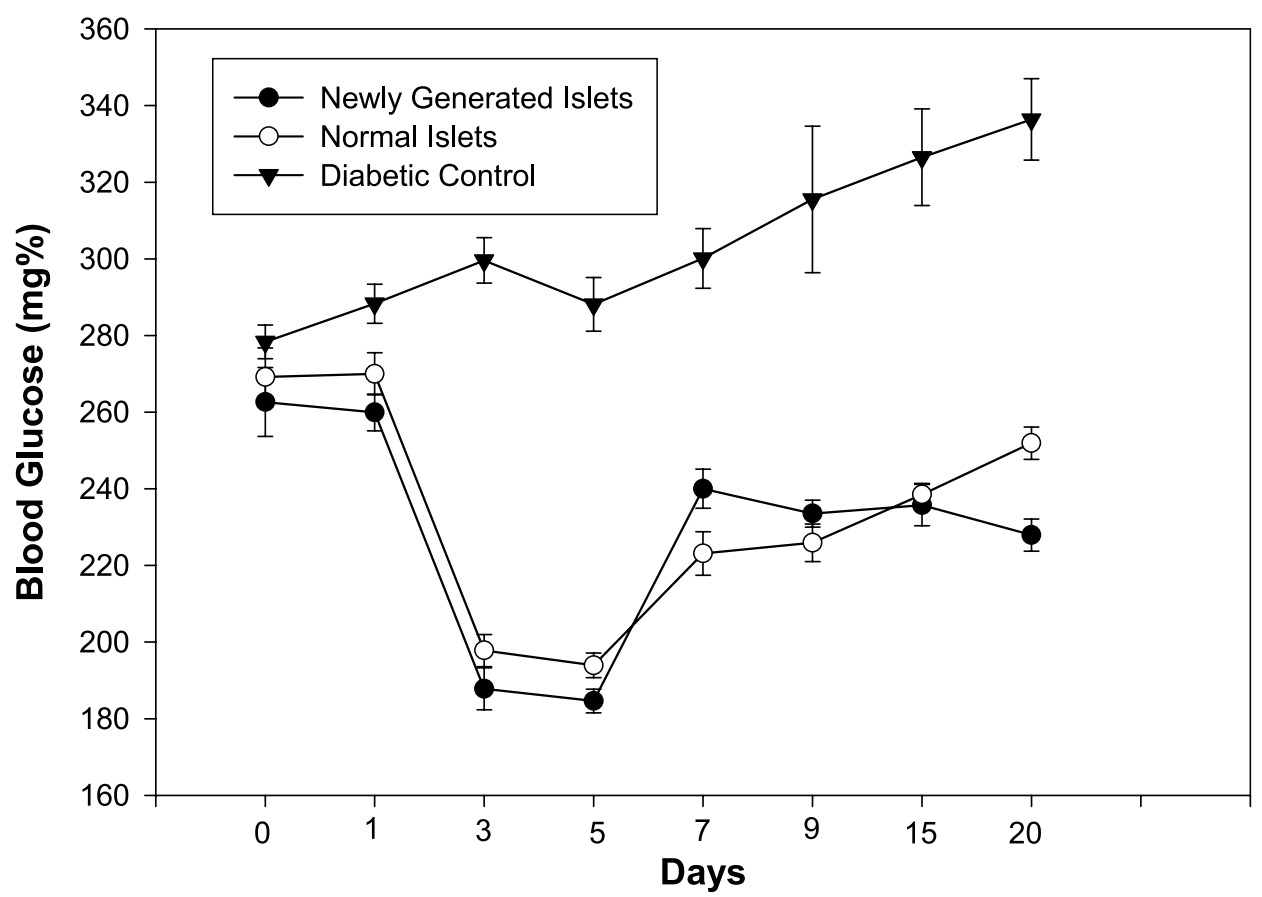

Figure 5 Blood glucose levels after islet transplantation.

newly generated islet phenotypes were ascertained by the presence of insulin-specific DTZ staining (Bonner-Weir et al. 2000, Shiroi et al. 2002), Western blotting and mRNA expression of insulin, glucagon, GLUT-2, Reg-1 and PDX-1 genes. The serum-free culture medium used in these studies contains keratinocyte growth factor, a known stimulant for the growth of epithelial cells (Bonner-Weir et al. 2000), with some modifications such as the addition of 2-mercaptoethanol which effectively restricted the growth of fibroblast cells and enhanced the growth of epithelial cells. A striking feature of our system was the reproducible recovery of a large number of islets from ductal culture within a span of 3-4 months, demonstrating that a continuous supply of islets could be made available for transplantation. Inclusion of mouse serum as reported earlier (Ramiya et al. 2000) did not yield satisfactory growth of islets in our system which could reflect on the strain of mice used.

Islet cell generation from pancreatic ductal stem cell cultures exhibited a definite pattern appearing in chronological order. Large islets $\left(7957 \pm 316 \mu \mathrm{m}^{2}\right)$ appeared within 4-5 weeks and progeny of small-sized islets $\left(1324 \pm 49 \cdot 3 \mu \mathrm{m}^{2}\right)$ appeared thereafter followed by withering out of epithelial cells. When we used conditioned medium from islet cell cultures of 4-5 weeks for successive passages, we observed an increase in islet cell generation. These findings suggest the plausibility of paracrine secretion or extracellular matrix components secreted by ductal epithelial cells which induce islet cell neogenesis and promote islet cell maturation. From the chronological appearance of islets and the assessment of their functionality it was clear that newly generated small-sized islets respond to L-arginine stimulation depicting their fetal ontogeny (Nielsen et al. 2003) whereas large-sized islets respond to glucose stimulation depicting their mature nature. This shift in secretagogue response seems to be highly conserved suggesting an embryonic pattern of development. Intraperitoneal transplantation of regenerated islets and islets isolated from the normal adult pancreas in diabetic animals showed a reduction in circulating glucose levels.

Circulating glucose levels were found to be slowly elevated over 20 days, but they still remained lower than in their diabetic counterparts. We did not monitor these animals further as our objective was limited to check in vivo functionality of neoislets in terms of insulin secretion. Cryopreservation of islets for 6 months did not affect the functional characteristics of the regenerated islets as evidenced by glucose challenge experiments, further revealing the possibility of islet banking which is highly sought after. However, there was a gross reduction in insulin secretion noticed due either to loss of viability of islets or to the culture conditions. Reduction in insulin secretion was also reported previously by Nielsen et al. (2002) with transplantation studies using porcine islets.

In summary, we have optimized culture conditions such as the extracellular matrix and modified the media to obtain a consistent yield of large numbers of islets from mouse pancreatic ductal epithelial cells needed for 
transplantation. These islets secrete insulin in response to stimulation of an appropriate secretagogue depending upon the developmental stage of the islets.

\section{Acknowledgements}

The authors wish to thank the Director, National Centre for Cell Science, Pune, India for extending all the facilities to carry out the present work. The authors would like to make a special mention of Drs D Mitra and M R Wani for scientific discussions, Ms Ashwini Atre for taking the confocal images and Ms R C Patwardhan for the preparation of the manuscript (all from NCCS, Pune, India).

\section{Funding}

The study was financed by Dept. of Biotechnology, Gov. of India.

\section{References}

Bhattacharya E, Panchal A, Wilkins TJ, De Ondarza J \& Hootman SR 1995 Insulin, transforming growth factors and substrates modulate growth of guinea pig pancreatic duct cells in vitro. Gastroenterology 109 944-952.

Bonner-Weir S, Taneja M, Weir GC, Tatarkiewicz K, Song K, Sharma A \& O'Neill JJ 2000 In vitro cultivation of human islets from expanded ductal tissue. PNAS 97 7999-8004.

Brockenbrough JS, Weir GC \& Bonner-Weir S 1988 Discordance of exocrine and endocrine growth after $90 \%$ pancreatectomy in rats. Diabetes 37 232-236.
Cornelius JG, Tchernev V, Kao KJ \& Peck AB 1997 In vitro generation of islets in long term cultures of pluripotent stem cells from adult mouse pancreas. Hormone Metabolism Research 29 271-277.

Gmyr V, Kerr-Conte J, Vandewalle B, Proye C, Lefebvre J \& Pattoou F 2001 Human pancreatic ductal cells: large scale isolation and expansion. Cell Transplantation 10 109-121.

Gu D \& Sarvetnik N 1993 Epithelial cell proliferation and islet neogenesis in IFN-9 transgenic mice. Development 118 33-46.

Hardikar AA, Karandikar MS \& Bhonde RR 1999 Effect of partial pancreatectomy on diabetic status in BALA/C mice. Journal of Endocrinology 162 189-195.

Nielsen TB, Yderstraede KB \& Beck-Nielsen H 2002 Isolation, transplantation and functional studies of adult porcine islets of Langerhans. Comparative Medicine 52 127-135.

Nielsen TB, Yderstraede KB, Schroder HD, Holst JJ, Brusgaard K \& Beck-Nielsen H 2003 Functional and immunohistochemical evaluation of porcine neonatal islet-like cell clusters. Cell Transplantation 12 13-25.

Ramiya VK, Maraist M, Afors KE, Schatz DA \& Peck AB 2000 Reversal of insulin dependent diabetes using islets generated in vitro from pancreatic stem cells. Nature Medicine 6 278-282.

Shewade YM, Umrani M \& Bhonde RR 1999 Large scale isolation of islets by tissue culture of adult mouse pancreas. Transplantation Proceedings 31 1721-1723.

Shiroi A, Vostrikava M, Yokota M, Tatsumi K \& Takahashi Y 2002 Identification of insulin producing cells derived from embryonic stem cells by zinc-chelating dithizone. Stem Cells 20 284-292.

Slade JMW 1995 Developmental biology of the pancreas. Development 121 1569-1580.

Vogel G 1999 Harnessing the power of stem cells. Science $\mathbf{2 8 3}$ 1468-1470.

Received 9 January 2004

Accepted 2 March 2004

Made available online as an

Accepted Preprint 15 March 2004 